associated with the surface of dendritic processes of reticular cells, where it comes in contact with lymphoeytes. By contrast, in the medullary sinuses antigen is retained intracellularly in the inclusions of typical phagocytic cells. The distribution of label in lymphoid follicles leads us to suggest that the term 'phagocytic reticulum' which we have previously used ${ }^{4}$ in relation to this area should be replaced by the term 'antigen-retaining reticulum'. It is tempting to speculate that the two patterns of lymph node antigen distribution reflect different facets of the immune processes.

We thank Prof. G. J. V. Nossal and Dr. G. L. Ada for their advice and Mr. J. Pye for performing the iodinations. This work was supported by grants from the National Institute of Allergy and Infectious Diseases, U.S. Public Health Service $(A I-0-3958)$, to Prof. Nossel, and from the National Health and Medical Research Council, Australia. Some batches of iodine-125 were a gift of Glaxo Laboratories, England.

Judith Mitchell

Walter and Eliza Hall Institute, A. Aвbot

Melbourne, Australia.

${ }^{1}$ Ada, G. X., Nossal, G. J. V., Pye, J., and Abbot, A., Nature, 199, 1257, Part II (1963).

${ }^{2}$ Nossal, G. J. V., Ada, G. L., and Austin, C. M., Austral. J. Exp. Biol. and Med. Sci., 42, 311 (1964). ${ }^{3}$ Ada, G. S., Nossal, G. . . V., and Austin, C. M., Austral. J. Exp. Biol. and

' Miller, J. J., and Nossal, G. J. V., J. Exp. Med., 120, 1075 (1964).

Ada, G. L., Nossal, G. J. V., and Pye, J., Austral. J. Exp. Biol. and Med. Sci., 42,295 (1964)

'Palade, G. E., J. Exp. Med., 95, 285 (1952).

' Mitchell, J. (submitted for publication to $J$. Immunol.).

'Mayor, H. D., Hampton, J. C., and Rosario, B., J. Biophys. Biochem. Cytol, 9,909 (1961).

'Salpeter, M. M., and Bachmann, L., J. Cell Biol., 22, 469 (1964).

${ }^{10}$ Luft, J. (personal communication).

${ }^{11}$ Dowell, W. C. T., Fourth Intern. Conf. Electron Microscopy, Berlin, 1958, 1, $375(1960)$.

${ }^{22}$ Fleming, W., Arch. Mikr. Anat., 24, 550 (1885).

\section{Zinc and Other Metallic lons as Hatching Agents for the Beet Cyst Nematode, Heterodera schachtii Schm.}

Some inorganic salts stimulate eggs of the beet cyst nematode, Heterodera schachtii Schm., to hatch, but less effectively than diffusate from sugar-beet roots ${ }^{1-3}$. The effective ions are potontial oxidizing agents. We have extended hatching tests to some metallic ions not previously tried, including $\mathrm{Ba}^{2+}, \mathrm{Al}^{3+}, \mathrm{Pb}^{2+}, \mathrm{MoO}_{4}^{-}$, $\mathrm{Mn}^{2+}, \mathrm{Co}^{2+}, \mathrm{Zn}^{2+}$ and $\mathrm{Cd}^{2+}$, and have re-tested some salts $\left(\mathrm{MgCl}_{2}, \mathrm{KCl}, \mathrm{NaCl}, \mathrm{HgCl}_{2}\right.$ and $\left.\mathrm{FeCl}_{3}\right)$. Copper, previously tested as the sulphate, was tested as the chloride, and chlorides of the other metals were included in tests whereever possible. All salts were first tested at a concentration of $\sim 3 \mathrm{mM}$ in water and those with some activity wore tested again over a range of concentrations. The hatch of eggs (Table 1 ) is expressed as a hatch rating ${ }^{3}$ :

$$
\frac{H_{s}-H_{w}}{H_{d}-H_{w}} \times 100
$$

where $H_{s}$ is the hatch in the substance, $H_{d}$ is the hatch in beet root diffusate and $H_{w}$ is the hatch in distilled water, and also as a percentage of the total number of eggs in the eysts.

Zinc sulphate, zinc nitrate and zinc and cadmium chlorides proved potent hatching agents; twelve other salts were moderately or weakly active, and ten were inactive or inhibitory. The zine salts and cadmium chloride are more effective than the other inorganic hatching agents for $H$. schachtii ${ }^{3}$ although neither anion nor cation is a potential oxidizing agent. The activity of these two chlorides (zine and cadmium) was not caused by hydro. chloric acid formed by hydrolysis, because hydrochloric acid itself is only moderately active at its optimum concentration.
Table 1. ThE ABILITY OF Various Metallic SALTS to stimulate Hatching OF $H$. schach CENTAGE OF THE TOTAL NUMBER OF EGgS IN THE CYSTS

Based on total hatch after three weeks from three batches of 100 cysts

\begin{tabular}{|c|c|c|c|}
\hline Compound & $\begin{array}{l}\text { Concentration } \\
(\mathrm{mM})\end{array}$ & $\begin{array}{l}\text { Hatch } \\
\text { rating }\end{array}$ & $\begin{array}{l}\text { Percentage } \\
\text { hatch }\end{array}$ \\
\hline Zine chloride & $4^{*}$ & $180 \dagger$ & 64 \\
\hline Cadmium chloride & $0.6 *$ & $17 y$ & 56 \\
\hline Zine sulphate & 2 & 127 & 55 \\
\hline Zine nitrate & 2 & 113 & 45 \\
\hline Ammonium molybdate & $\overline{3}^{*}$ & 82 & 38 \\
\hline Lead acetate & $3 *$ & 75 & 23 \\
\hline Aluminium chloride & $3 *$ & 69 & 32 \\
\hline Manganese chloride & ${ }_{3}^{*}$ & 66 & 32 \\
\hline Cobalt chloride & $0 \cdot 6 *$ & 60 & 31 \\
\hline Ferrous sulphate & 2 & 59 & 23 \\
\hline Zine acetate & $\overline{2}$ & 57 & 27 \\
\hline Cadmium sulphate & $0.6 *$ & 56 & 34 \\
\hline Barium chloride & $3 *$ & 54 & 27 \\
\hline Calcium chloride & $3 *$ & 53 & 18 \\
\hline Cadmium nitrate & $0 \cdot 6 *$ & 31 & 22 \\
\hline Ferrous ammonium sulphate & 1 & 26 & 16 \\
\hline Lead nitrate & $2 *$ & 22 & 20 \\
\hline Potassium chloride & $\overline{3}$ & 19 & 11 \\
\hline Ferric chloride & $0 \cdot 6 *$ & 16 & 20 \\
\hline Sodium chloride & 3 & 15 & 11 \\
\hline Cupric chloride & $0.6 *$ & 4 & 20 \\
\hline Ammonium nitrate & 8 & $-14 \ddagger$ & 10 \\
\hline Ammonium sulphate & 4 & $-15^{+}$ & 10 \\
\hline Magnesium chloride & 3 & -30 & 14 \\
\hline Sodium nitrate & & -88 & 1 \\
\hline Mercuric chloride & $0.6 *$ & -95 & 1 \\
\hline
\end{tabular}

* Optimum concentration in a dilution series.

Bold type indicates hatch as good as or better than in root diffusate. which is $100+10$

$\ddagger$ Negative sign indicates percentage inhibition compared with the hatch in water, which is $0 \pm 10$.

Because of its potency in causing $H$. schachtii eggs to hatch, we tested the ability of zine chloride to hatch eggs of other Heterodera species: $H$. avenae, $H$. carotae, $H$. cruciferae, $H$. glycines, $H$. goettingiana, $H$. rostochiensis, $H$. tabacum and $H$. trifolii. With $H$. avenae, where the number of eggs which hatch in oat-root diffusate and in water is the same, zine chloride inhibited hatching slightly. With $H$. goettingiana, where only very few eggs hatch either in water or in pea,-root diffusate in vitro, a few more larvae hatched out in zinc chloride. With all the other species, zinc chloride caused more eggs to hatch than did water, and with most of these species hatching was as great as or greater than that in the root diffusate from their host plants. As with other agents that stimulate hatching, it is not known how $\mathrm{Zn}^{2+}$ and $\mathrm{Cd}^{2+}$ ions act.

A. J. Clarke

AUdREy M. Shepherd

Rothamsted Experimental Station, Harpenden, Hertfordshire.

Rademacher, R., and Schmidt, O., Arch. PfBau, 10, 237 (1933).

${ }^{2}$ Wallace, H. R., Ann. App. Biol., 44, 274 (1956).

${ }^{3}$ Clarke, A. J., and Shepherd, A. M., Nematologica, 10, 431 (1964).

\section{Failure of the Zona Reaction in Five Pig Eggs}

Is most mammals which have been examined, the first spermatozoon that penetrates into the egg stimulates the egg to undergo a reaction which prevents subsequent spermatozoa from traversing the zona pellucida ${ }^{1}$. This phenomenon is called the 'zona reaction'. In the pig, following the zona reaction, spermatozoa can still penetrate into the zona but they normally cannot traverse it". However, eggs aged for several hours before exposure to the first spermatozoon sometimes fail to elieit the zona reaction and several spermatozoa enter the vitellus (polyspermy) to become male pronuclei (polyandry) ${ }^{3}$.

In the course of examining several hundred recently fertilized pig eggs, we observed five eggs which did not exhibit a zona reaction. The first of these came from a litter of nine eggs recovered about $8 \mathrm{~h}$ after ovulation. Eight of these were at normal stages while one egg (egg $A$ ) was unusual in that it contained two spermatozoa in the perivitelline space (Fig. 1). After the egg was fixed in acetic-alcohol and stainod with orcein, a vesicular nucleus was revealed (Fig. 2). Hancock ${ }^{4}$ reported that out of 1,677 pig eggs examined, three had vesicular nuclei. The second egg that had not undergone a zona reaction came from a litter of five eggs recovered $54 \mathrm{~h}$ after insemination. 